\title{
USGS Activities at Lake Roosevelt and the Upper Columbia River
}

Lake Roosevelt (Franklin D. Roosevelt
Lake) is the impoundment of the upper
Columbia River behind Grand Coulee

Dam, and is the largest reservoir within the Bureau of Reclamation's Columbia Basin Project (CBP). The reservoir is located in northeastern Washington, and stretches 151 miles from Grand Coulee Dam north to the Canadian border (fig. 1). The 15-20 miles of the Columbia River downstream of the border are riverine and are under small backwater effects from the dam. Grand Coulee Dam is located on the mainstem of the Columbia River about 90 miles northwest of Spokane. Since the late 1980s, trace-element contamination has been known to be widely present in Lake Roosevelt. Trace elements of concern include arsenic, cadmium, copper, lead, mercury, and zinc. Contaminated sediment carried by the Columbia River is the primary source of the widespread occurrence of trace-element enrichment present in Lake Roosevelt. In 2001, the U.S. Environmental Protection Agency (EPA) initiated a preliminary assessment of environmental contamination of the Lake Roosevelt area (also referred to as Upper Columbia River, UCR site, or UCR/ LR site) and has subsequently begun remedial investigations of the UCR site.

Many large landowners have interests in the reservoir and surrounding lands, including the Department of the Interior. The upland area surrounding Lake Roosevelt is thinly populated and consists primarily of forests. The Bureau of Reclamation operates Grand Coulee Dam, and the National Park Service manages the Lake Roosevelt (LARO) National Recreation Area. The Colville
Confederated Tribes and the Spokane Tribe of Indians have large reservations bordering parts of the reservoir, but both Tribes' "usual and customary" hunting and fishing grounds are accepted as including the entire reservoir. Federal lands administered by the U.S. Forest Service Colville National Forest and the Bureau of Land Management, and much private land also border the reservoir.

The region of the upper Columbia River Basin is rich in mineral deposits. Beginning in the mid to late 1800 s, widespread mining activities occurred for various metals, primarily gold, silver, copper, lead, and zinc. These mineral deposits also contained antimony, arsenic, iron, manganese, cobalt, and molybdenum. Several smelters and numerous mines have been built and operated in the upper Columbia River Basin. The

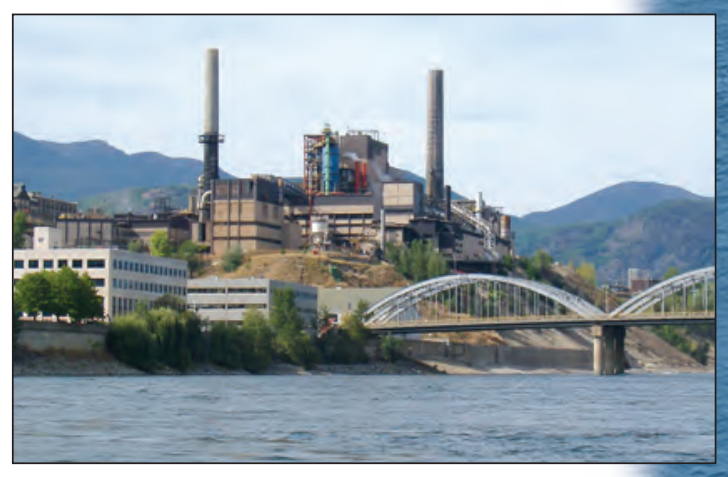

Teck Smelter at Trail, British Columbia, Canada. only remaining operational smelter in the basin is located 10 miles upstream of Lake Roosevelt at Trail, British Columbia, now owned by Teck Resources Limited of Canada. The complex includes one of the world's largest integrated lead-zinc smelting facilities, and in 2009, annual production was 240,000 tons of refined zinc and 73,000 tons of refined lead (Teck Resources Limited, 2010), with smaller quantities of silver, gold, cadmium, bismuth, and many other associated metal products. For nearly a century, metallurgical and industrial wastes from the smelter, including process wastewater and slag, have been discharged to the Columbia River (fig. 2). Effluent treatment and upgrades in metals refinement technology since 1981 have greatly reduced the quantities of metals discharged to the Columbia River. The discharge of slag to the river was discontinued in 1995. Improvements in river health adjacent to the smelter following the operational upgrades at the smelter have been well documented (G3 Consulting, Ltd., 2001).

Other industrial discharges affecting Lake Roosevelt include the Celgar pulp mill located in Castlegar, British Columbia. Prior to modernization completed in 1993, effluent from the pulp mill was discharged to the Columbia River without significant treatment, and water quality of the Columbia River downstream of the Celgar pulp mill was reported (Butcher, 1992; Hatfield Consultants Ltd., 2005) to be substantially affected from effluent that contained dioxins and furans. Modernization of the mill and the installation of effluent treatment systems in 1993 greatly reduced dioxins and furans from the mill effluent (Serdar and others, 1994; Hatfield Consultants Ltd., 2005). 


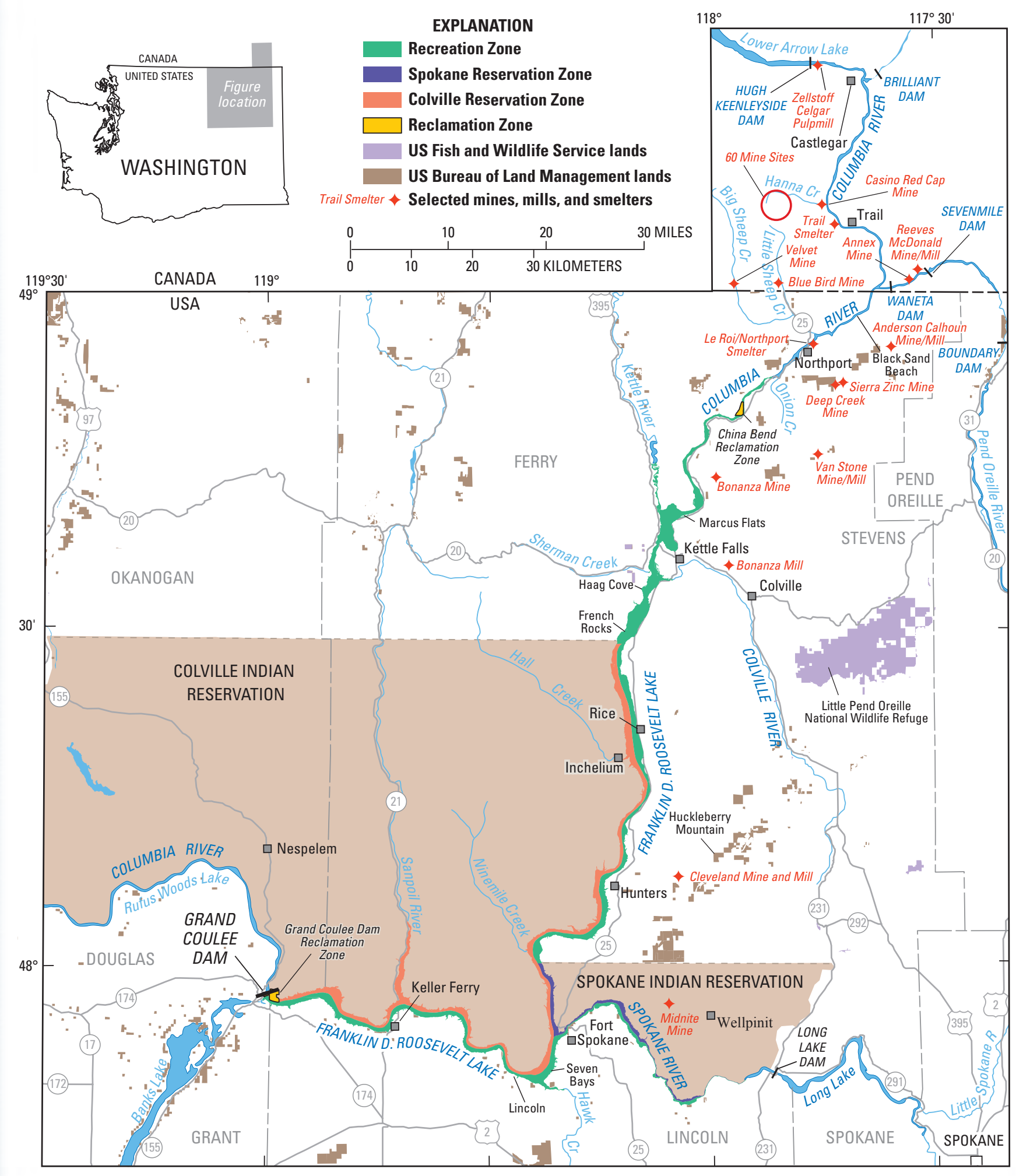

Figure 1. Location of Lake Roosevelt, northeastern Washington. 


\section{Early USGS Work on the Resources of the Upper Columbia River Basin}

The USGS has conducted numerous studies in the Lake Roosevelt area on a wide range of topics. Most of the studies prior to 1992, although germane to the present contamination issues in the area, were not initiated by concerns of contamination. The earliest work was on geology and mineral deposits (Pardee, 1918) in support of mining activities in the area. In the years shortly after the reservoir was filled, shoreline landslides were frequent and the USGS conducted landslide studies and seismic surveys to better describe these conditions (Jones, 1954; Jones and others, 1961). Miscellaneous geologic studies of varved lakebeds (Walker, 1967) and glacial lake deposits in the Sanpoil basin (Atwater, 1986) also have been conducted. The USGS conducted early water-availability studies for the communities of Wellpinit (Foxworthy and Washburn, 1956) and Inchelium (M.J. Grolier, U.S. Geological Survey, written commun., 1961), as well as for the National Recreation Area (Anderson, 1969).

Recent studies by the USGS have investigated gas bubble trauma in fish downstream of the dam (Beeman and others, 2003) and ways to reduce the entrainment of native salmonids through turbines by the use of strobe lights (Perry and others, 2002, 2003). White sturgeon are culturally and economically important throughout the Columbia River Basin. White sturgeon are benthic-oriented fish that can grow to be very large (maximum 20 feet long and 1,800 pounds) and very old (more than 100 years). Their numbers have been decreasing in Lake Roosevelt; and, although spawning has been observed, few non-hatchery juvenile sturgeons have been observed.

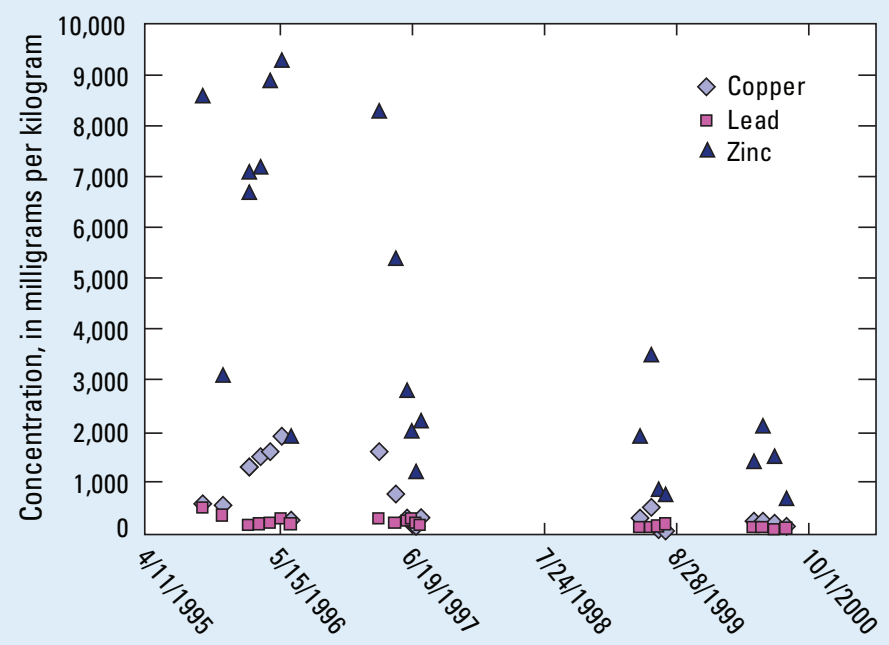

Figure 3. Concentrations of metals in suspended sediment in the Columbia River near the Canadian border.

\section{USGS Work Related to Contamination in Lake Roosevelt}

\section{Sediment Quality Assessments}

A study by the USGS in 1992 (Bortleson and others, 2001) was the first integrated approach to study metals and chlorinated hydrocarbons in the reservoir sediments, and serves as a benchmark for later studies. Recent studies have focused on metals contamination in water, sediment, fish, and air. The primary metals of interest are arsenic, cadmium, copper, lead, mercury, and zinc, all of which are present to some degree in the discharges from the Teck smelter.

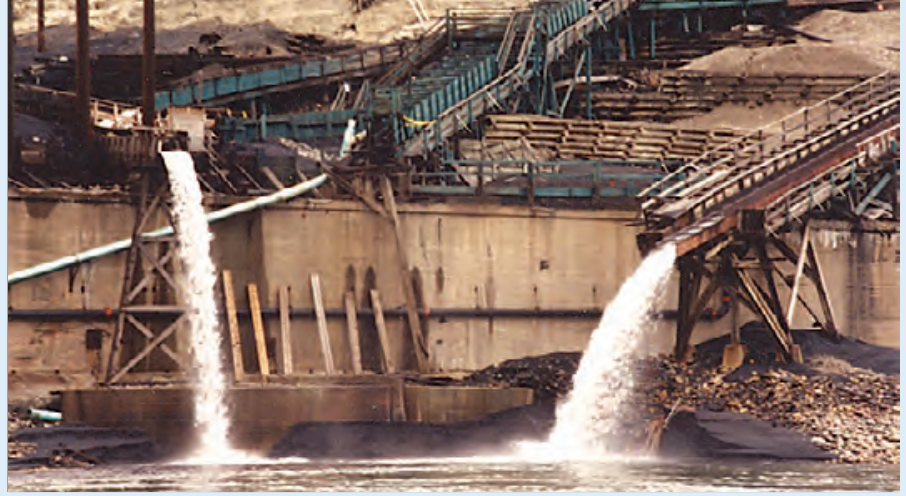

Figure 2. Outfall of Teck smelter in Trail, British Columbia, circa 1992.

Data from Bortleson (2001) and the USGS National Stream Accounting Network (NASQAN, Kelly and others, 2001) show that concentrations of dissolved metals in the Columbia River near the Canadian border have historically been relatively high, but are presently substantially lower. This decrease is believed to be related to improvements in effluent treatment and reductions in the discharge of metals from the Teck smelter to the Columbia River. However, because the annual mean flow of the Columbia River at the border typically is about 100,000 cubic feet per second, loads of these dissolved metals to the reservoir remain quite large.

\section{Concentrations of dissolved metals in the Columbia River at the Canadian border, 1992.}

[Concentrations are in micrograms per liter]

\begin{tabular}{|c|c|c|c|c|}
\hline Arsenic & Cadmium & Copper & Lead & Zinc \\
\hline $0.3-0.5$ & $0.06-0.1$ & $1.6-1.7$ & $0.6-0.9$ & $3.0-6.2$ \\
\hline
\end{tabular}

Sediment is transported in the Columbia River to Lake Roosevelt suspended in the water and as bedload during high flows. Concentrations of metals on the suspended sediment at the Canadian border are quite large, but have decreased in recent years (Kelly and others, 2001; fig. 3). Because of upstream Canadian and United States dams, suspended-sediment concentrations in the Columbia River at the Canadian border are actually quite low. Consequently, suspended sediment accounts for only about 10-60 percent of the metals discharged by the Columbia River into the lake, as compared to more than 90 percent of the metals for typical large rivers.

Slag also is present along with the natural sediments present in the upper reaches of Lake Roosevelt (fig. 4), a glassy granular waste product of the smelting process that was discharged from the Teck smelter. Slag can form deposits along the shore under high-flow conditions (fig. 5). Similar slag deposits may exist in the reservoir at depth along the original river channel, as a result of pre-reservoir floods. In such cases, the slag deposits may be buried under layers of finer grain, post-reservoir sediment.

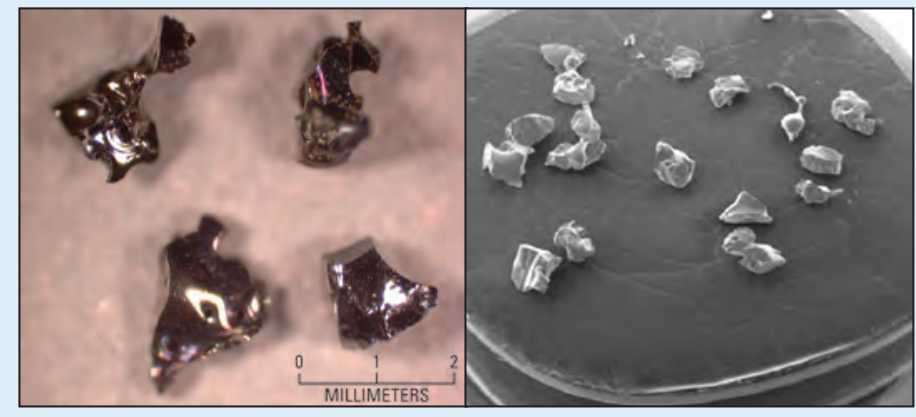

Figure 4. Photograph and Scanning Electron Microscope images of slag grains. 
Majewski and others (2003) found elevated concentrations of arsenic, cadmium, copper, mercury, lead, and zinc in shallow, nearshore sediments along the reservoir. Concentrations for most metals decreased down-reservoir (fig. 6). These results are typical of other sediment studies of Lake Roosevelt, including an EPA Site Investigation conducted in 2002.

In 2002, the USGS collected sediment cores from six locations in the mid-channel of Lake Roosevelt that showed that the largest metals concentrations were deeper within the accumulated sediments; or, conversely, lower concentrations of most metals were in the more recent deposits (Cox and others, 2005; fig. 7). This pattern reflects decreases over time in metals discharges from the Teck smelter. Concentrations in several cores show sections of low concentrations (fig. 8) believed to be associated with landslide deposits and(or) bank erosion. These deposits interrupt and mix with regular fluvial sedimentary deposition processes. The landslides also are believed to have been a significant source of sediment to the reservoir. Cox and others (2005) also showed that slag within the reservoir sediment is not as chemically stable as reported for recently created slag. The slag does weather and continues to be a source of metals to the water column and, thus, to the biota. As the slag weathers through a hydration process, surface layers flake off (fig. 9). Energy-dispersive X-ray analysis indicates that the newly exposed surface has a higher calcium and zinc concentration than the older weathered surface, providing a new source of zinc to the water. Paulson and others (2006) measured not only (1) the concentrations of dissolved metals in interstitial water of sediments that were released from solid sediment, but also measured (2) the release rates of bioavailable dissolved metals that were released to the water column during gently stirred incubation core experiments, and (3) the release rates from slurries mixed end-over-end. For all three measures, the highest dissolved copper concentrations were associated with sediment samples collected from the riverine reach near the Canadian border that contained 70 percent slag based on the sediment zinc concentration (Paulson and Cox, 2007).

\section{Air-Quality Assessments}

The Lake Roosevelt area can be subject to severe dust storms at times during the winter and spring. The USGS and the Colville Confederated Tribes operated an air monitoring network to study the airborne concentrations of metals during these events during the winter and spring from 2002 to 2006 . Airborne concentrations of smelter-related metals were very low to date, even though

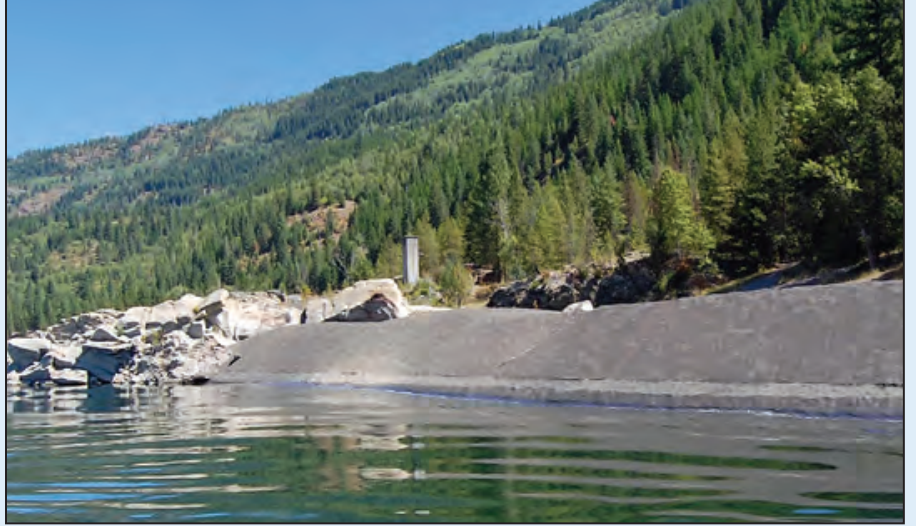

Figure 5. Deposits of slag along the Columbia River near the Canadian border. The slag is the darker deposits.
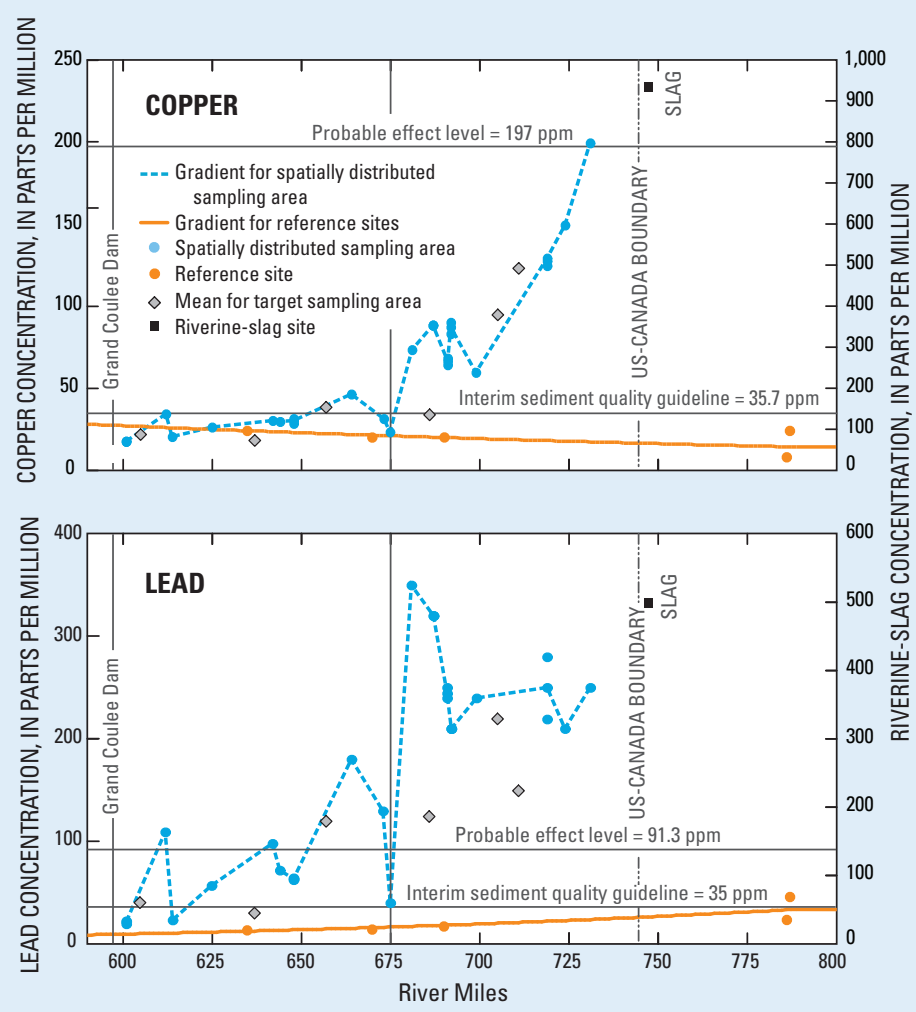

Figure 6. Concentrations of copper and lead in Lake Roosevelt sediment, by river mile (RM). RM 600 is at Grand Coulee Dam, RM 750 is near the Canadian border.

\section{CCR-692}
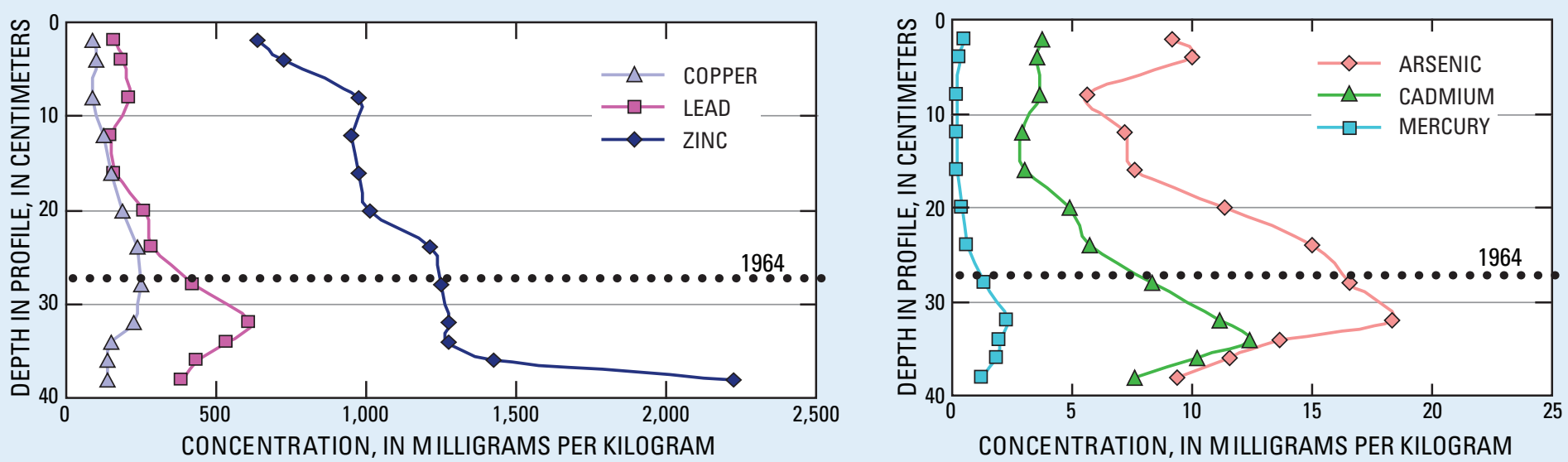

Figure 7. Concentrations of metals in sediment with depth at Core CCR-692 located halfway between Kettle Falls and Inchelium. 
high wind events were recorded; this may be because reservoir drawdowns and, thus, the area of exposed sediment was minimal during those years. The only regulatory standards in effect are for total suspended particulate matter and airborne lead, and neither was exceeded.

\section{Ecological Health Assessments}

In a 1994 study, the USGS found copper, manganese, mercury, selenium, and zinc in fillets of walleye, trout, and smallmouth bass (Munn and others, 1995). Only the mercury in fish fillets was at concentrations to be of concern to human health, and the Washington State Health Department issued an advisory for the consumption of fish from Lake Roosevelt (Erwin and Munn, 1997). Concentrations of cadmium, copper, lead, and zinc were detected in the liver tissue of these same fish, but no physiological effects were noted. A followup study in 1998 (Munn, 2000), showed that concentrations of mercury, dioxins, and furans in fish fillets significantly decreased (fig. 10). The decreases were attributed to improvements in effluent treatment at the Teck smelter and the elimination of dioxins and furans from the effluent of the Celgar pulp mill.

The USGS also has investigated the toxicity of the sediment and bioaccumulation of metals by benthic invertebrates. Besser and others (2008) showed three of the four end-points in sediment toxicity tests (amphipod survival, amphipod growth, and midge growth) differed significantly among the sediments tested. The data indicated low amphipod survival (71 percent) from only one site, and highly variable survival in sediments from three other sites. That study also shows bioaccumulation of five metals (copper, cadmium, lead, arsenic, and zinc) in Oligochaete Worms at concentrations higher than concentrations measured in reference sediments - copper, cadmium, and lead were substantially higher at factors of 20, 47, 22 times, respectively.

The USGS is presently completing an interdisciplinary study to further understand the effects of slag on white sturgeon in Lake Roosevelt. The study consists of several elements, including using multi-beam sonar to map water depths and videography to map sediment texture in two areas (Marcus Flats and China Bend) of

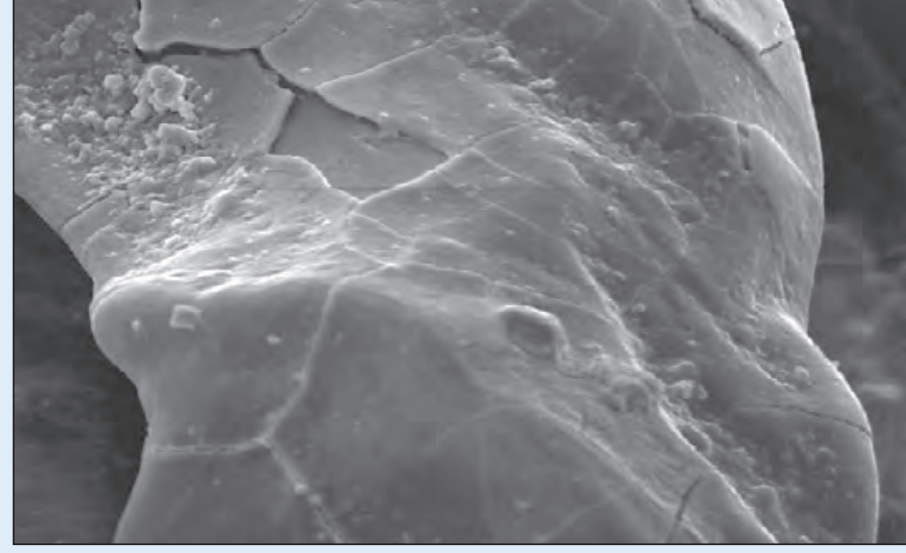

Figure 9. Scanning Electron Microscope image of slag grain. Concentrations of calcium and zinc are larger on the exposed inner surface compared to the outer surface. The size of the missing flake is about $40 \times 20$ microns.
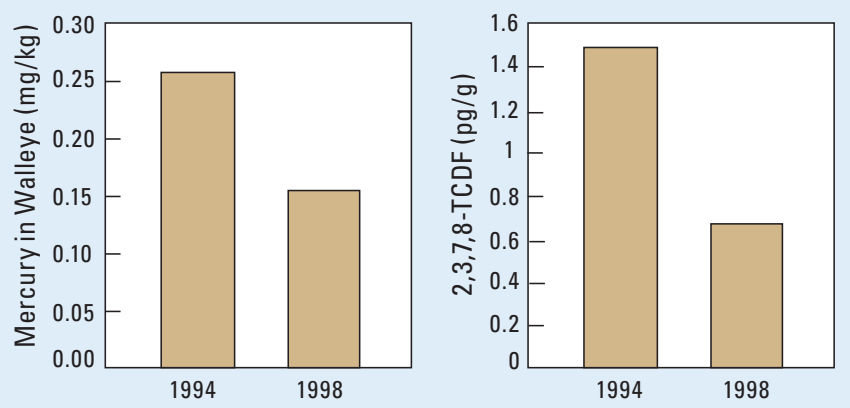

Figure 10. Concentrations of mercury in walleye and furans in rainbow trout.

sturgeon habitat. Concurrently, sturgeons were tracked acoustically by the Washington Department of Fish and Wildlife to determine their patterns of movement in these areas. A soon-to-be-completed study of the diet of juvenile white sturgeon captured from this area showed that the diet primarily was benthic in origin and most fish had consumed slag. Results of histological analysis of the Lake Roosevelt white sturgeon should reveal if inflammation in the gastrointestinal tracts of Lake Roosevelt fish is greater than that seen in hatchery-reared white sturgeon.
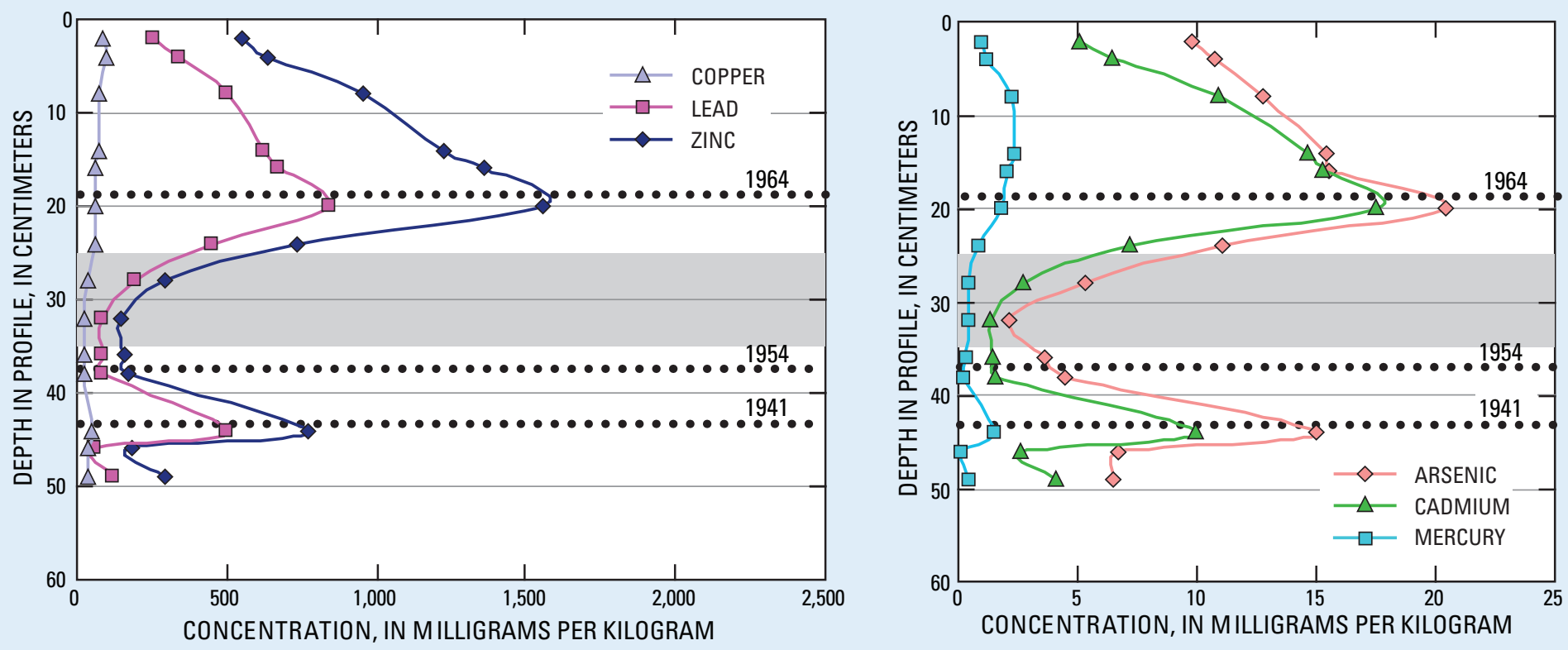

Figure 8. Concentrations of metals in sediment with depth at Core CCR-705 located just north of Kettle Falls. Note section in the middle of the core associated with a landslide deposit, delineated in gray. Dotted lines are time stratigraphic horizons. 


\section{References Cited}

Anderson, H.W., Jr., 1969, Water supplies for Coulee Dam National Recreation Area, Washington: U.S. Geological Survey Open-File Report 69-8, $141 \mathrm{p}$.

Atwater, B.F., 1986, Pliestocene glacial-lake deposits of the Sanpoil River Valley, northeastern Washington: U.S. Geological Survey Bulletin No. 1661, 39 p.

Beeman, J.W., Venditti, D.A., Morris, R.G., Gadomski, D.M., Adams, B.J., VanderKooi, S.J., Robinson, T.C., and Maule, A.G., 2003, Gas bubble disease in resident fish below Grand Coulee Dam-Final report of research: Report to Bureau of Reclamation, $159 \mathrm{p}$.

Besser, J.M., Brumbaugh, W.G., Ivey, C.D., Ingersoll, C.G., and Moran, P.W., 2008, Biological and chemical characterization of metal bioavailability in sediments from Lake Roosevelt, Columbia River, Washington, USA: Archives of Environmental Contamination and Toxicology, v. 54, p. 557-570.

Bortleson, G.C., Cox, S.E., Munn, M.D., Shumaker, R.J., and Block, E.K., 2001, Sediment-quality assessment of Franklin D. Roosevelt Lake and upstream reach of the Columbia River, Washington, 1992: U.S. Geological Survey Water-Supply Paper 2496, $130 \mathrm{p}$.

Butcher, G. A., 1992, Lower Columbia River, Hugh Keenleyside Dam to Birchbank, Water Quality Assessment and Objectives, Technical Appendix: British Columbia Ministry of Environment, Water Quality Branch, Victoria British Columbia, 202 p.

Cox, S.E., Bell, P.R., Lowther, J.S., and VanMetre, P.C., 2005, Vertical distribution of trace element concentrations and occurrence of metallurgical slag particles accumulated bed sediments of Lake Roosevelt, Washington, September 2002: U.S. Geological Survey Scientific Investigations Report 2004-5090, 70 p. (Also available at http://pubs.usgs.gov/sir/2004/5090/.)

Erwin, M.L., and Munn, M.D., 1997, Are walleye from Lake Roosevelt contaminated with mercury?: U.S. Geological Survey Fact Sheet 102-97, 4 p. (Also available at http://wa.water.usgs. gov/pubs/fs/fs.102-97/.)

Foxworthy, B.L., and Washburn, R.L., 1956, Reconnaissance investigation of ground water in the Wellpinit area, Stevens County, Washington: U.S. Geological Survey Open-File Report 56-46, $14 \mathrm{p}$.

G3 Consulting, Ltd., 2001, Assessment of Columbia River receiving waters, Final Report: Prepared for Teck Cominco Metals, Ltd., Trail Operations, by G3 Consulting, Ltd., Burnaby, British Columbia, 183 p.

Hatfield Consultants Ltd., 2005, Celgar Pulpmill Environmental Effects Monitoring (EEM) Cycle Four Design Document: Prepared for Celgar Pulp Company by Hatfield Consultants Ltd., West Vancouver, June 2005

Jones, F.O., 1954, Landslide conditions along the Ferry County highway paralleling Lake Roosevelt from Kettle Falls to the mouth of the Spokane River, Washington: U.S. Geological Survey Open-File Report 54-136, 35 p., 9 pls.

Jones, F.O., Embody, D.R., Peterson, W.L., and Hazelwood, R.M., 1961, Landslides along the Columbia River valley, northeastern Washington, with a section on seismic surveys: U.S. Geological Survey Professional Paper 367, 98 p.

Kelly, V.J., Hooper, R.P., Aulenbach, B.T., and Janet, Mary, 2001, Concentrations and annual fluxes for selected water-quality constituents from the USGS National Stream Quality Accounting Network (NASQAN), 1996-2000: U.S. Geological Survey Water-Resources Investigations Report 01-4255. (Also available at http://pubs.usgs.gov/wri/wri014255/.)
Majewski, M.S., Kahle, S.C., Ebbert, J.C., and Josberger, E.G., 2003, Concentrations and distribution of slag-related trace elements and mercury in fine-grained beach and bed sediments of Lake Roosevelt, Washington, April-May 2001: U.S. Geological Survey Water-Resources Investigations Report 03-4170, 29 p. (Also available at http://pubs.usgs.gov/wri/wri034170/.)

Munn, M.D., 2000, Contaminant trends in sport fish from Lake Roosevelt and the upper Columbia River, Washington, 19941998: U.S. Geological Survey Water-Resources Investigations Report 00-4024, 12 p. (Also available at http://wa.water.usgs. gov/pubs/wrir/wrir00-4024.pdf.)

Munn, M.D., Cox, S.E., and Dean, C.J., 1995, Concentrations of mercury and other trace elements in walleye, smallmouth bass and rainbow trout in Franklin D. Roosevelt lake and the upper Columbia River, Washington, 1994: U.S. Geological Survey Open-File Report 95-195, 35 p.

Pardee, J.T., 1918, Geology and mineral deposits of the Colville Indian Reservation, Washington: U.S. Geological Survey Bulletin $677,186 \mathrm{p}$.

Paulson, A.J., and Cox, S.E., 2007, Release of elements to natural water from sediments of Lake Roosevelt: Environmental Toxicology and Chemistry, v. 26, no. 12, p. 2550-2559.

Paulson, A.J., Wagner, R.J., Sanzolone, R.F., and Cox, S.E., 2006, Concentrations of elements in sediments and selective fractions of sediments, and in natural waters in contact with sediments from Lake Roosevelt, Washington, September 2004: U.S. Geological Survey Open-File Report 2006-1350, 84 p.

Perry, R.W., Farley, M.J., Darland, T.J., Hansen, G.S., Feil, D.H., Rondorf, D.W., and LeCaire, R., 2002, Feasibility of using 3D acoustic telemetry to assess the response of resident salmonids to strobe lights in Lake Roosevelt, WA: Annual report for 2001 by U.S. Geological Survey to Bonneville Power Administration, BPA project No. 1995-011-02, Portland, Oregon.

Perry, R.W., Farley, M.J., Hansen, G.S., Shurtleff, D.J., Rondorf, D.W., and LeCaire, R., 2003, Using 3D acoustic telemetry to assess the response of resident salmonids to strobe lights in Lake Roosevelt, Washington, 2002: Annual report for 2002 by U.S. Geological Survey to Bonneville Power Administration, BPA project No.1995-001-02, Portland, Oregon.

Serdar, Dave, Yake, Bill, and Cubbage, James, 1994, Contaminant trends in Lake Roosevelt: Washington State Department of Ecology, Publication No. 94-185, 58 p.

Teck Resources Limited, 2010, Determination: 2009 Annual Report: Vancouver, British Columbia, 122 p., accessed June 8, 2010, at http://www.teck.com/.

Walker, E.H., 1967, Varved lake beds in northern Idaho and northeastern Washington: U.S. Geological Survey Professional Paper 575-B, p. B83-B87.

\section{Author: Cynthia Barton and Gary L. Turney Design: Bill Gibbs}

\section{For more information, contact :}

Director, USGS Washington Water Science Center U.S. Geological Survey

934 Broadway, Suite 300, Tacoma, WA 98402 Phone: (253) 552-1600 Email: dc_wa@usgs.gov http://wa.water.usgs.gov/ 